\title{
TEACHER TRAINEES' EXPERIENCES OF INCLUSIVE PRACTICES DURING TEACHING PRACTICE
}

\author{
William Nketsia \\ Western Sydney University, Australia \\ Maxwell Peprah Opoku \\ University of Tasmania, Australia \\ Eric Lawer Torgbenu \\ University of Health and Allied Sciences, Ghana
}

\begin{abstract}
Teaching practice has been found to significantly improve teacher trainees' understanding of special educational needs (SEN) and knowledge of inclusive teaching practices. Using a descriptive survey design and a purposive sample of final-year teacher trainees $(n=171)$, college supervisors $(n=57)$ and school-based mentors $(n=77)$ from three public colleges of education in Ghana, this study explored teacher trainees' experiences regarding the inclusive practices they learnt, their collaboration with stakeholders and the challenges they encountered during teaching practice. The study reveals that teaching practice does not adequately promote inclusive practical training of teacher trainees and that mentors do not model effective inclusive practices for trainees. The study found an immeasurably small number of co-teaching practices among trainees. The implications of the findings for the improvement of teaching practice in effectively training teachers in areas of SEN and inclusive education in colleges of education are also discussed.
\end{abstract}

Keywords: Inclusive education, Inclusive practices, Teaching practice, Teacher trainees.

\section{Introduction}

The participants of the World Education Forum in Dakar, Senegal (26-28 April 2000), established that it is the human right of all children, young people and adults to benefit from an education that is capable of meeting their basic needs in the best and fullest sense of the term, an education that includes learning to know, to do, to live together and to be (UNESCO, 2000). To achieve these goals, the participants promised to create a safe, healthy, inclusive and equitably resourced educational environment 
that is conducive to the learning and achievement of all children. Inclusive education has been described in the Salamanca Statement as "regular education with child-centred pedagogy capable of meeting the special needs of pupils" (UNESCO, 1994, p. 5). Inclusive education aims to transform schools by eliminating all forms of discrimination, so as to offer quality education for all, while respecting and celebrating diversity in relation to the learning needs, abilities and characteristics of all students. It is about schools creating inclusive cultures, producing inclusive policies and evolving inclusive practices (Ainscow et al., 2006).

Building on international declarations as well as national commitments such as sections of the 1992 Constitution of Ghana, the Education Strategic Plans of 2003-2015 and 2010-2020 and the National Development Agenda to achieve Education for All - Ghana has adopted inclusive education within the framework of Universal Design for Learning as a strategy to address the diverse learning needs of all students. The policy seeks to attain inclusive education for all persons with to and severe SEN at all levels of education (Ministry of Education, 2015). Hence, several studies and reports (e.g. Alhassan, 2014; Ministry of Education, 2015; Singal et al., 2015) have confirmed that, due to the limited provision of special education facilities and in line with the policy of inclusive education, a majority of students with SEN are attending mainstream schools. This finding is consistent with other studies from sub-Saharan African countries (Arbeiter \& Hartley, 2002; Sawhney, 2015).

However, similar reports and studies have also established that, due to certain barriers, students with SEN in mainstream settings are largely ignored and denied active participation in the classroom (CaselyHayford et al., 2013; Sawhney, 2015). Meanwhile, inclusive education involves valuing, supporting and increasing the full participation of all students within the cultures, curricula and communities of mainstream educational settings (Ainscow et al., 2006; Dyson, 2014). Barriers to the implementation of inclusive education include inaccessible school buildings, lack of appropriate facilities in schools, lack of appropriate teaching and learning materials, lack of extra support in the classroom for children with disabilities, social stigma and negative societal attitudes to disability and poverty. In addition, inadequate teacher training has been identified as another key barrier to the implementation of inclusive education in Ghana and other African countries (Agbenyega \& Deku, 2011; Alhassan, 2014; Alhassan \& Abosi, 2014: Le Fanu, 2013). Studies have also found that initial teacher education programmes do not adequately equip teachers with the knowledge and skills required for inclusive practices (Nketsia, Saloviita, \& Gyimah, 2016; Nketsia \& Saloviita, 2013). Hence, mainstream classroom teachers lack the requisite knowledge and skills to 
adequately address the special needs of students in mainstream classrooms. The dominant instructional approaches adopted by mainstream classroom teachers generally take the form of teachers asking questions and writing on chalkboards, with students passively listening, writing and shouting out answers (Le Fanu, 2013; Sawhney, 2015). This raises critical questions with respect to the adequacy of initial teacher education programmes, especially the teaching practice component, to effectively equip trainees with inclusive practices. Inclusive practices are the actions that teachers take to give meaning to the concept of inclusion; they are the practices that respond to the diversity among learners (Florian \& Black-Hawkins, 2011). Studies have shown that a lack of inclusive practices results in the social isolation and marginalization of students in inclusive settings (Sawhney, 2015) and that their adoption have yielded positive results (Florian \& Black-Hawkins, 2011).

Globally, initial teacher training has been found to play a crucial role in preparing teachers to successfully implement inclusive education (Arbeiter \& Hartley, 2002; Dart, 2006; Florian \& Rouse, 2009). This important role has been emphasized in several international documents, such as UNESCO's Policy Guidelines on Inclusion in Education (2009) and the 2006 Convention on the Rights of Persons with Disabilities. Collectively, these documents agreed that pre-service and in-service teacher education programmes should adopt inclusive education approaches and materials in order to equip prospective teachers with the appropriate inclusive skills, knowledge, attitudes and pedagogical capacities to enable them to address the diverse learning needs of different categories of learners.

In an attempt to prepare teachers for inclusive settings, different initial teacher education programmes have added one or two separate SEN courses to equip teacher trainees with the appropriate knowledge, skills and competencies to be effective inclusive teachers (Sharma et al., 2008; Strawderman \& Lindsey, 1995; Welch, 1996). However, some studies have established that one or two SEN courses are inadequate to provide teacher trainees with the necessary knowledge for the expected roles, functions and responsibilities required of inclusive education settings (Jelas, 2010; Wolfberg et al., 2009). Globally, many of these courses have been found to provide limited knowledge on SEN and inclusive pedagogical skills and have lacked focus on practical issues (Dart, 2006; Lawson et al., 2013; Nash \& Norwich, 2010; Tungaraza, 2014).

Consequently, trainees and qualified teachers have expressed feelings of ill-preparedness with regard to dealing with SEN and disability issues within inclusive classrooms (Chhabra et al., 2010; Lambe \& Bones, 2006; Lawson et al., 2013; Sawhney, 2011; Sharma et al., 2008). The evidence suggests that higher education-based training and education alone do not 
result in professional reflection (Nash \& Norwich, 2010). The creation of classroom settings that are inclusive of all students requires the training of regular education teachers in receiving adequate knowledge and highlevel exposure to theory and practice regarding how to address the diverse needs of students with SEN. To address the aforementioned shortcomings of the one to two SEN courses in initial teacher education, many researchers have recommended that trainees be provided not only with theoretical knowledge but also with school placement opportunities in inclusive settings to effectively develop their attitudes towards disabilities as well as skills to enable them to address the special needs of all students (Dart, 2006; Lambe, 2007).

Indeed, several studies have identified school-based learning (teaching practice) as a relevant aspect of teacher education and training for inclusive education (Dart, 2006; Florian \& Rouse, 2009; Lawson et al., 2013; McIntyre, 2009; Nash \& Norwich, 2010). These studies have established that well-structured teaching practices or field-based experiences can effectively improve trainees' knowledge and understanding about SEN and inclusive education practices. One key feature of such teaching practices is that trainees spend more time in school placement, thus shifting some of the responsibilities of their knowledge development regarding issues of SEN and inclusion to placement schools. Teaching practice includes innovative structured fieldwork approaches, such as the involvement of a practical teaching task that is SEN- and student-focused, though it does not focus on practical teaching (Lawson et al., 2013; Strawderman \& Lindsey, 1995). These planned tasks are designed to enable trainees to engage in direct teaching experience with an individual learner with identified SEN under the supervision of a SEN coordinator in order to significantly improve trainees' knowledge and understanding about SEN and inclusive practices (Dart, 2006; Lawson et al., 2013; Nash \& Norwich, 2010). So far, it is not known whether the one-year teaching practice in the colleges of education in Ghana includes planned practical tasks with an individual or group of students with identified SEN or provides school-based formative, reflective and assessment tasks to promote critical reflection among student teachers.

Moreover, studies have shown that the teaching practices of trainees during school-based placement are mostly determined by their mentors and that these mentors can prevent them from innovatively practicing what they were taught in their initial teacher education programme (Angelides et al., 2006). Therefore, to effectively adopt teaching practice as an approach to equip teacher trainees with knowledge and understanding about SEN and inclusive practices, placement schools and mentors must be carefully selected. Placement schools must have quality inclusive education provisions, training support systems and well-trained mentors who can 
provide trainees with quality SEN and inclusive training (Nash \& Norwich, 2010). Schools which support inclusive education promote positive attitudes among its teachers. Moreover, the mentoring of newly qualified teachers under the supervision of experienced teachers with an inclusive philosophy has positive implications for inclusive teacher education. This enables teacher trainees to develop a commitment to inclusion (Forlin, 2010, p. 251). However, it is unclear what impact the one-year teaching practice has on trainees and the knowledge and understanding of SEN and inclusive practices they are exposed to by mentors.

Mentoring creates opportunities for teachers' voices to be heard and provides a bridge between theory and practice; above all, it allows for the co-construction of knowledge between newly trained teachers and mentors to create a community of practice to support each other through informal professional learning, which is an important component of teacher education (West, 2010). Such experiential learning opportunities and mentorship have been found to be effective in preparing teachers to apply their new knowledge in classrooms (West et al., 2006) and can significantly promote teacher training in inclusive education (EADSNE, 2012). For this to become a reality, teacher education programmes must work in strong partnership with placement schools on practical activities for teacher training on SEN and inclusive education (McIntyre, 2009). Apart from the nature and quality of the partnership arrangement between initial teacher education programmes and partner schools, the quality of training that student teachers receive in their partner schools also depends on the clarity of the responsibilities and the communication between the partners (Nash \& Norwich, 2010).

Furthermore, West (2010) considered opportunities for collaboration, consultation and problem solving across common educational environments as other essential elements of teaching practice in the effective training of teacher trainees. Thus, trainees and beginning teachers should be given opportunities to work collaboratively with stakeholders to build their confidence, knowledge and skills. Such collaboration with mentors, fellow trainees and parents has been found to influence trainees' guidance in their teaching more so than collaboration with their college lecturers and tutors (Clarke et al., 2012). Currently, the nature of trainee collaboration with other stakeholders during teaching practice is unknown.

\section{Teaching practice in Ghana's colleges of education}

The three-year teacher education diploma programme for basic school teachers in Ghana follows an 'in-in-out' scheme in which trainees spend the first two years in the college carrying out course work. They then 
spend their final year in a basic school classroom teaching, acquiring practical classroom experience and developing teaching competencies with the support of in-service teachers (mentors) and college-based teacher educators (supervisors). During teaching practice, trainees prepare weekly lesson plans, which are evaluated by their supervisors. Supervisors also embark on a series of scheduled visits to observe and examine lessons and to provide feedback (Akyeampong et al., 2012). Ghana's recent inclusive education policy emphasizes the training of pre-service and in-service teachers in inclusive education to enable them to identify and respond to the needs of each child, promote diversity in the classroom and make schools' curricula, assessment procedures, teaching and learning materials accessible and fair for all learners (Ministry of Education, 2015). However, it is not clear the extent to which the teaching practice component of the pre-service teacher training promotes the training of pre-service and in-service teachers in inclusive education to enable them to identify and respond to the needs of each child. Therefore, the specific objective of this survey was to determine trainees' experiences of SEN and inclusive practices during teaching practice. The study set out to determine:

1. The main activities mentees performed during teaching practice

2. Inclusive practices trainees learned during teaching practice

3. Mentees' collaboration with other stakeholders during teaching practice

4. The challenges faced by mentees in addressing SEN among pupils during teaching practice.

\section{Methodology}

\section{Study Participants}

The participants comprised 171 final-year teacher trainees (mentees), 57 college course tutors (supervisors) and 77 school-based practicing teachers (mentors) from three public colleges of education in Ghana. For the purpose of the study, participants with particular characteristics were of highest interest to the study; the supervisors were college course tutors who were involved in teaching practice supervision; the mentors were school-based practicing teachers who were responsible for mentoring the final-year teacher trainees in the placement schools; and the mentees were the final-year teacher trainees on teaching practice.

A description of the participants' demographics is presented in Table 1. All the mentees had completed a course on SEN, had their teaching practice in a mainstream basic school and indicated that they identified pupils with disabilities and SEN during their teaching practice. According to the mentors, the number of pupils with SEN in their various classes 
ranged from 1 to $10(M=2.03, S D=1.51)$. The sizes of the classrooms taught by the trainees ranged from 30 to $100(M=51.22, S D=15.58)$.

Table 1. Description of participants

\begin{tabular}{|l|c|c|c|c|c|c|c|c|c|c|}
\hline $\begin{array}{c}\text { Partici- } \\
\text { pants }\end{array}$ & N & $\begin{array}{c}\text { Return } \\
\text { Rates }\end{array}$ & \multicolumn{2}{|c|}{$\begin{array}{c}\text { Gender } \\
\%\end{array}$} & \multicolumn{2}{c|}{ Age } & \multicolumn{4}{c|}{$\begin{array}{c}\text { Qualifications } \\
\%\end{array}$} \\
\hline & & $\%$ & Male & Female & Range & M & $\begin{array}{c}\text { Certifi- } \\
\text { cate A }\end{array}$ & $\begin{array}{c}\text { Diplo- } \\
\text { ma }\end{array}$ & $\begin{array}{c}\text { De- } \\
\text { gree }\end{array}$ & $\begin{array}{c}\text { MA/ } \\
\text { MPhil }\end{array}$ \\
\hline Mentees & 171 & 63 & 57 & 43 & $23-33$ & 26.8 & - & - & & \\
\hline Supervisors & 57 & 38 & 75 & 25 & $28-61$ & 45.0 & - & 1 & 25 & 74 \\
\hline Mentors & 77 & 57 & 61 & 39 & $23-61$ & 40.1 & 10 & 43 & 45 & 2 \\
\hline
\end{tabular}

\section{Instruments}

The aim of this study was to explore the final-year teacher trainees' experiences during teaching practice. Hence, the quantitative descriptive survey design employed involved the administration of a written questionnaire that mainly consisted of open or free-response questions (Oppenheim, 1992; Pallant, 2016). The questionnaire was designed from previous studies on initial teacher preparation in enabling teachers to meet the needs of students with disabilities (see e.g. Clarke et al., 2012: Dart, 2006; Forlin, 2010; Lawson et al., 2013; Nash \& Norwich 2008, 2010; West, 2010). A draft of the questionnaire was reviewed by two academics outside the research team, who had research interest in teacher preparation for inclusive education, to ensure that relevant data were collected to address the research questions. The final draft was tried on twenty teacher trainees from a college of education that was not included in the study. The questionnaires were then amended based on the pilot report before the data collection.

The questionnaire consisted of two main sections for all the respondents of the three different surveys. Section A elicited information on the respondents' backgrounds (e.g. age, gender, qualifications, completion of SEN course, etc.). Section B consisted of a varied range of closed- and open-ended questionnaire items. One dichotomous question with response options ( $1=$ Yes, $2=$ No) required mentees to indicate whether they collaborated among themselves as mentees and with others during teaching practice. The open-ended questionnaire items requested all participants (mentees, mentors and supervisors) to describe the main activities that mentees performed during their teaching practice. Another open-ended item requested mentees and supervisors to describe assignments provided during the one-year teaching practice, which encouraged mentees to reflect on how to address the diverse learning needs of pupils. Also, the mentees 
were asked to describe the best inclusive practices they learned during teaching practice, their collaboration with others and among themselves and the main challenges they encountered as far as addressing the special needs of pupils was concerned. Further, mentees who had the opportunity to observe the lesson delivery of their mentors were asked to describe the main instructional strategies used by the mentors during lesson delivery. The mentors were also asked to indicate the number of students with SEN in their class.

\section{Data collection procedure}

Due to the wide geographical spread of the placement schools, three colleges of education were conveniently selected on the basis of their familiarity, accessibility and proximity to the first author. They included College A situated in the Western Region, College B in the Central Region and College $\mathrm{C}$ in the Ashanti Region. A letter was then sent to all the principals of the selected colleges to seek their permission to collect the data. Following their consent, the first author contacted the teaching practice coordinators, the head teachers of the placement schools and the lead mentees to inform them about the study and sought their assistance with mentee recruitment. The first author personally delivered 200 survey questionnaires to mentees, 100 to mentors and another 100 to supervisors in all the accessible placement schools. To assure the participants of their confidentiality and anonymity, all the questionnaires contained cover letters explicitly explaining the purpose of the research and requiring them not to indicate their names or that of their colleges. The participants were also informed that the completion of the survey implied their consent to participate in the study and that they were free to withdraw at any time. In all the schools visited during the data collection, two mentees were assigned to one mentor; therefore, they shared a classroom with the mentor.

\section{Data analysis}

The data obtained were analysed in two phases. First, the responses to the closed-ended questions were entered into the IBM SPSS Statistics Program 25. Simple frequency and percentage analyses were used in the analysis of the demographic data and the responses to the dichotomous question, which required mentees to indicate whether they collaborated among themselves during teaching practice. Second, coding frames were developed for each open-ended question (Oppenheim, 1992; Pallant, 2016). A convenient number of twenty questionnaires from the mentees and ten questionnaires each from the mentors and supervisors were used to develop the coding frame for each of the open-ended questions. Thus, each of the openended questions was copied on a separate Microsoft Word document, as 
they appeared in the questionnaire, followed by all the responses to that question. Each answer was preceded by the case number.

Bearing in mind the aims of the study and the specific purpose of the question under consideration, the first and second authors coded the selected questionnaires independently, followed by a discussion and resolution of the differences between them to eliminate inconsistencies and ambiguities. The first author then used the agreed coding frames to code all the responses to the open-ended questions by highlighting and coding the specific segments of the responses. The first and second authors agreed on the themes under which to present the codes and the response segments to be extracted for analysis. The first author proceeded to write the first draft of the analysis, which was read and accepted by all the authors. Some of the major themes were assigned a numerical code and entered into the IBM SPSS Statistics Program 25, together with the quantitative data. The results were presented using simple percentages and frequency distribution tables.

\section{Results}

\section{The main activities mentees performed during teaching practice}

The mentees, mentors and supervisors were asked to describe the main activities that mentees performed during teaching practice. Seven broad themes emerged from the analysis: the preparation of lesson notes, preparation of teaching and learning materials, classroom teaching and learning, the management of student behaviour in the classroom, taking part in extracurricular activities and assessing students' academic performance. Observation of the delivery of lessons by mentors was mentioned by very few mentees (13\%). Table 2 below summarises the broad themes.

Table 2. The main activities mentees performed during teaching practice

\begin{tabular}{|l|l|l|l|}
\hline \multicolumn{1}{|c|}{ Main Activities } & $\begin{array}{c}\text { Mentees } \\
\%\end{array}$ & $\begin{array}{c}\text { Supervisors } \\
\%\end{array}$ & $\begin{array}{c}\text { Mentors } \\
\%\end{array}$ \\
\hline Preparation of lesson notes & 99 & 65 & 86 \\
\hline Classroom teaching and learning & 88 & 95 & 91 \\
\hline Management of student behaviour in classroom & 69 & 51 & 84 \\
\hline Taking part in extracurricular activities & 79 & 70 & 82 \\
\hline Assessing of student academic performance & 82 & 65 & 78 \\
\hline Preparation of teaching materials & 100 & 63 & 70 \\
\hline Observing the delivery of lessons by mentors & 13 & & \\
\hline
\end{tabular}




\section{Inclusive practices mentees learned during teaching practice}

The mentees were asked to list some of the best inclusive practices they learnt during their teaching practice, from which 12 major themes emerged, including writing boldly on the chalkboard (66\%), speaking louder (61\%), code switching (60\%), questions and answers (56\%), seating arrangements (50\%), the use of teaching and learning materials (46\%), the use of practical activities (45\%) and revision of relevant previous knowledge (19\%). However, only few mentees mentioned collaboration with parents (18\%), cooperative learning (15\%), collaboration with other stakeholders (14\%) and the use of mixed-ability grouping (13\%). Table 3 below summarizes the responses.

The next question asked the mentees to indicate whether they had an opportunity to observe the lesson delivery of their mentors during teaching practice and to list some of the teaching methods/instructional strategies most commonly used by their mentors. Only few mentees (12\%) indicated that they had an opportunity to observe their mentors' lessons. The instructional strategies most commonly used by the observed mentors included lectures (62\%), exchange of ideas among teacher and students through discussion (62\%), demonstration (56\%), asking and answering questions (49\%), practical activities to engage student (33\%), generating and gathering ideas through brainstorming (31\%), role play (27\%) and the discovery method (18\%).

Table 3. The inclusive practices learnt by mentees during teaching practice

\begin{tabular}{|l|c|}
\hline Inclusive Practices & $\begin{array}{c}\text { Trainees } \\
(\mathrm{N}=171) \\
\%\end{array}$ \\
\hline Writing boldly on the chalkboard & 66 \\
\hline Speaking louder for everyone to hear & 61 \\
\hline Code switching to ensure understanding & 60 \\
\hline The use of questions and answers to engage students & 56 \\
\hline Arrangement of seats & 50 \\
\hline The use of Teaching and learning Materials & 46 \\
\hline Engaging students in practical activities & 45 \\
\hline Revising relevant previous knowledge & 19 \\
\hline Collaborating with parents & 18 \\
\hline Cooperative learning & 15 \\
\hline Collaboration with other stakeholders & 14 \\
\hline Mixed ability grouping & 13 \\
\hline
\end{tabular}




\section{Mentees' collaboration during teaching practice}

The mentees were then asked to indicate whether they engaged in collaboration among themselves as mentees and with other stakeholders during teaching practice and to describe how they collaborated. Almost all of them (95\%) indicated that they had collaborated. The coding yielded nine categories, all of which were related to their collaboration among themselves. Therefore, all the categories were organized under an umbrella theme 'mentees' collaboration among themselves'. The mentees collaborated by discussing examination papers (61\%), assisting each other in preparing teaching and learning materials (49\%), sharing ideas on how to plan lessons (47), consulting each other on subject matter (45\%), consulting each other on appropriate teaching methods (23\%) and co-teaching (8\%).

Additionally, the mentees were asked to mention whether their assignments or course work made them reflect on how they addressed the learning needs of pupils with SEN in their placement classroom. The supervisors were asked to indicate whether they provided mentees with assignments or coursework during the one-year teaching practice that made mentees reflect on how they addressed the diverse learning needs of students with SEN. The mentees and supervisors were then asked to list some of the assignments provided. Only nine percent of supervisors indicated that they had provided mentees with assignments; seven percent mentioned that they had provided assignments relating to guidance and counselling, and five percent indicated that they had provided assignments relating to classroom management. However, none of the mentees confirmed that such assignments had been provided during teaching practice.

\section{The challenges faced by mentees during teaching practice}

In the final part of the survey, all mentees were asked to list the main challenges they encountered during their teaching practice as far as addressing the diverse learning needs of students was concerned. The coding yielded eighteen categories, which were organized under five major umbrella themes, namely: students' characteristics, teachers' characteristics, collaboration with stakeholders, physical environment and resources.

Under the 'students' characteristics' theme, the mentees indicated that the diverse learning needs of students and lack of interest of students in learning presented enormous challenges to them during teaching practice. Under the 'teachers' characteristics' theme, they mentioned inadequate teacher preparation and their inability to engage all students in lessons. With regard to collaboration with stakeholders, the mentees found lack of parental cooperation to be most challenged during teaching practice. They also indicated that the lack of teaching and learning materials presented 
enormous challenges in terms of resource availability. Under the 'physical environment' category, large class sizes and inaccessible physical environments were mentioned. The results are presented in Table 4.

Table 4. Challenges trainees encountered as far as meeting the special needs of pupils were concerned

\begin{tabular}{|l|c|}
\hline Challenges encountered by Mentees & $\begin{array}{c}\text { Mentees } \\
(\mathrm{N}=171) \%\end{array}$ \\
\hline Student characteristics & 49 \\
\hline Stigmatization of students with SEN & 44 \\
\hline Students' lack of interest in learning & 43 \\
\hline Emotional and behavioral problems among students & 40 \\
\hline The diverse learning needs of students & \\
\hline Resources & 59 \\
\hline Lack of teaching and learning materials & 37 \\
\hline Inadequate desks & 32 \\
\hline Lack of specialists to assist us & 50 \\
\hline Teacher characteristics & 33 \\
\hline $\begin{array}{l}\text { Inadequate teacher preparation to address the special needs among } \\
\text { students }\end{array}$ & \\
\hline Lack of skills to engage all students in lesson & 45 \\
\hline Physical environment & 37 \\
\hline Large class size & 38 \\
\hline Inaccessible physical environment & 30 \\
\hline Collaboration with stakeholders & \\
\hline Lack of parental cooperation & \\
\hline Lack of cooperation with mentors & \\
\hline Lack of well-trained mentors & \\
\hline
\end{tabular}

\section{Discussion}

Authentic opportunities are required in order for teacher trainees to exercise their capabilities of translating theory into practice. One such opportunity is school-based learning (teaching practice), which forms part of many initial teacher education programmes. The first question in this study sought to describe the main activities that mentees performed during teaching practice. The main activities consistently mentioned by mentees, mentors and supervisors included preparation of lesson notes and teaching and learning materials, teaching and assessing student performance and 
management of student behaviour. These findings reflect those of Kuyini and Desai (2009), who observed that the teaching practices of regular classroom teachers were limited to class management and lesson presentations. One unanticipated finding was that only few mentees indicated that they had observed the lesson delivery of their mentors as part of the main activities performed during teaching practice. This is surprising because during teaching practice, two mentees share a classroom with their assigned mentor. It can therefore be assumed that mentees' observation of mentors' demonstration of inclusive attitudes, knowledge and skills is not a planned task or an expected activity during teaching practice. Previous studies have established that such observations by mentees promote critical reflection among mentees about their classroom teaching experiences (Dart, 2006; EADSNE, 2012; Nash \& Norwich, 2010).

Although the majority of mentors indicated that there were students with SEN in their various classes, the few mentees who had the opportunity to observe their mentors' lesson delivery indicated that the instructional approaches adopted by their mentors mainly included lectures, discussions, demonstrations, questions and answers, brainstorming, role play and the discovery method. These instructional approaches were likely to be unresponsive to the minority of students with SEN and disabilities. This finding is consistent with that of Agbenyega and Deku (2011), Alhassan and Abosi (2014) and Kuyini and Desai (2009), who found that regular classroom teachers in Ghana are unable to make adequate instructional adaptations to support children with disabilities. Inclusive education requires teachers to modify and adapt the curriculum and instructions to meet the diverse needs of students.

Consequently, some mentees and the majority of supervisors mentioned a lack of well-trained mentors and a lack of cooperation with mentors as some of the challenges they encountered in relation to addressing the diverse learning needs of students. It could therefore be argued that mentees might not fully benefit from observing mentors in terms of the acquisition of basic inclusive teaching competences. Studies have shown that mentees' views, beliefs and practices are mostly determined by their mentors (Angelides et al., 2006) and that they learn inclusive teaching practices from them during the mentoring and supervision process (Lawson et al., 2013). It is evident that the mentors themselves require professional development for the implementation of inclusive education. In-service teachers in similar contexts have expressed the need for 'in-house mentorship' and continuous professional development to equip them with key inclusive values and competences (Mangope \& Mukhopadhyay, 2015). This could also equip mentors with the capabilities to model appropriate inclusive teaching practices for trainees. 
With respect to the second research question, the most frequently mentioned inclusive practices mastered by the mentees were writing boldly, loud speaking, code switching to ensure understanding and questions and answers. Despite the presence of pupils with SEN in most classrooms, the teaching strategies adopted by both the trainees and mentors were less related to inclusive, child-centred and constructivist teaching approaches and did not require changes to planning and the curriculum, neither were adjustments made to the materials and instructional practices for special learners. Key inclusive practices - such as the physical arrangement of seats, revising previous knowledge, cooperative learning, mixed-ability grouping and collaborating with parents and other professionals - were only mentioned by a minority of mentees. Teachers who are committed to inclusive practices encourage cooperative and heterogeneous learning groups, activity learning, different seating arrangements and differentiated instructional approaches.

Globally, studies have shown that teaching practice can promote critical reflection among student teachers (Angelides et al., 2006; Clarke et al., 2012; Nash \& Norwich, 2010) and effectively prepare inclusive teachers (Dart, 2006; Lawson et al., 2013). The study showed that only a few supervisors provided assignments during teaching practice aimed at encouraging critical reflection among mentees. The assignments were only related to guidance counselling and classroom management. However, this account by the supervisors was not corroborated by the mentees. The presence of pupils with SEN in regular classrooms in Ghana presents an opportunity to assist trainees to familiarize themselves with inclusive practices and the needs of pupils with SEN. The findings of this study show that such opportunities were not deliberately created, suggesting that more needs to be done to ensure that these opportunities are fully utilized to equip trainees with inclusive practices. Teaching practice must create opportunities for trainees to examine their own beliefs and learn how to address the diversity of needs in the classroom (Jordan et al., 2009). The use of SEN/disabilityrelated tasks during teaching practice has a significant impact on trainees' knowledge and understanding of SEN as well as their attitudes towards inclusive education (Arbeiter \& Hartley, 2002; Dart, 2006; Lawson et al., 2013). Other promising teaching practice strategies include enabling trainees to become engaged in the direct teaching experience of pupils with identified SEN (Lawson et al., 2013), writing of portfolios (Angelides et al., 2006), assessment methods such as essays about SEN/disabilities, teaching plans and reports about teaching individuals and/or groups of pupils with SEN and peer- and self-review methods (Nash \& Norwich, 2010).

As part of teacher training, trainees should be provided with professional learning opportunities, such as consultation, coaching, communities of 
practice, mentoring, reflective supervision and technical assistance, etc. so as to develop collaborative skills that will enable them to engage in effective collaborative teaching (West, 2010). In this study, a majority of the trainees reported collaborating with their fellow trainees in study circles to discuss exam papers for external examinations, assisting each other with the preparation of teaching and learning materials, sharing ideas on how to plan lessons and consulting each other on subject matter and appropriate teaching methods. Only a minority actually engaged in co-teaching. These findings suggest that the mentees felt more comfortable consulting their fellow mentees to share ideas about teaching and learning than actually engaging in co-teaching with them. Co-teaching - a teaching approach whereby two or more people share responsibility for teaching - has been found to be effective in assisting teachers to serve all students fairly and equitably in general education classrooms (Villa et al., 1996). In the current study, while two trainees practiced their teaching in one classroom, only a few of them indicated that they had collaborated by means of co-teaching. Unsurprisingly, co-teaching was not identified as one of the best inclusive practices learnt during teaching practice. This might be partly attributed to the insufficient amounts of attention being paid to the development of trainees' co-teaching skills, thus resulting in a lack of such skills among trainees. Also, perhaps the importance of collaboration with other teachers through co-teaching might not have been taught or modelled to the trainees and was not part of the expected activities they had to perform during teaching practice. Elsewhere, trainees on teaching practice are expected to carry out co-teaching with their mentor in the early stages of their teaching experience in order to familiarize themselves with routines and programmes (Western Sydney University, 2018). Studies in similar contexts have found that while teachers acknowledged the importance of collaboration in implementing inclusive education, they lacked the skills to implement it (Mangope \& Mukhopadhyay, 2015; Swart et al., 2004). The ability of teachers to co-teach has been attributed to their pre-service and inservice training programmes (Villa et al., 1996). What is surprising is that the majority of mentees reported collaborating with their fellow trainees in study circles to discuss exam papers for external examinations. This finding arguably confirms the dominant examination-oriented culture in colleges of education and shows how it affects trainees' teaching practice.

Lastly, the mentees identified several factors that challenged their capacity to meet the special needs of pupils during teaching practice. The stigmatization of students with SEN was one of the challenges regarding students' characteristics most mentioned by the mentees. In Ghana, people tend to have strong views about disability, which are often based on stereotypes and traditional beliefs (Dako-Gyeke \& Asumang, 
2013). This finding raises intriguing questions about the effectiveness of public education regarding issues of disability in Ghana and implies that the government must invest more effort and resources in public sensitization programmes. Other challenges relating to students' characteristics included students' lack of interest in learning, emotional and behavioural problems among students and the great diversity in students' learning needs. These results are likely to be related to ineffective teacher preparation, resulting in an obvious lack of capacity among mentees in utilizing teaching strategies to effectively respond to the diversity of needs and abilities among pupils. Respect for diversity is a key inclusive value; diversity is a rich resource for learning, rather than a problem, and inclusive education welcomes diversity amongst all learners (UNESCO, 2009). Therefore, these findings suggest that teacher education programmes must be reformed to equip teachers with the understanding that students are individuals with diverse characteristics, interests and strengths and that they need to adopt different instructional strategies to engage students based on their diverse learning needs, interests and characteristics in the inclusive classroom.

Research has established that teachers need additional personnel assistance, adequate material resources, reduction in class sizes and accessible physical environments in order to effectively implement inclusive education (Scruggs \& Mastropieri, 1996). The mentees in this study encountered resource and physical barriers, such as lack of teaching and learning materials, inadequate desks and lack of specialist assistance, large class sizes and inaccessible physical environments. Above all, the majority of mentees described their own initial teacher education programme as ineffective in preparing them to address the special needs among students, and less than half indicated that they lacked the skills to engage all students in their classroom. These challenges are consistent with those cited by previous studies as barriers to the adoption of inclusive practices (Croft, 2010) and to achieving meaningful inclusive education in Ghana and other low-income countries (Casely-Hayford et al., 2013). These challenges have been found to impact negatively on teachers' attitudes toward inclusive education and are of great concern to teachers with regards to the implementation of inclusive education (Avramidis et al., 2000; Chhabra et al., 2010; Sawhney, 2015; Swart et al., 2004). Several authors have argued that these local contextual factors influence the way in which teaching strategies are interpreted, adapted and implemented (Tabulawa, 2013); thus, the teaching methods used by trainees and mentors might have been dictated by the conditions under which they teach. Moreover, collaboration with key stakeholders, such as other educational professionals, special educators, parents and communities, has been regarded as a core value for all teachers working in inclusive education (UNESCO, 2005). 
However, the present study described key stakeholders, such as parents and mentors, as uncooperative. This finding strengthens the earlier call for the implementation of professional development opportunities for key stakeholders, such as mentors and parents, to equip them with knowledge and skills to collaborate with mentees. Moreover, skills and strategies for collaboration should be incorporated into the teacher education curriculum to prepare mentees.

\section{Limitations of the current study}

The results of this study should be interpreted with due caution because of a number of limitations. First, to collect data, the study depended only on the accounts of pre-service teachers in conveniently selected schools. The pre-service teachers undertaking their teaching practice in different schools might have had different experiences from those reported here. We recommend that future studies adopt probability sampling to increase the generalizability of the results. Second, although the current study used a great deal of open-ended questions, the amount of space provided for the answers might have determined the length and fullness of the responses obtained. Future studies should adopt qualitative data collection approaches, such as interviews and observation, to capture information regarding the teaching practice experiences of pre-service teachers. Notwithstanding these limitations, this work offers valuable insights into the main activities that mentees perform during their teaching practice, the inclusive practices they learn during teaching practice, the extent of the collaboration among themselves during teaching practice, the impact of teaching practice on them and the challenges they face in addressing SEN among pupils during teaching practice.

\section{Implications for policymaking and conclusion}

This study showed that the presence of SEN pupils in mainstream classrooms was not fully utilized to prepare teachers on issues of SEN and inclusive practices. Teaching practice in initial teacher education should be reformed to improve teacher training for inclusive education. To support trainees' learning on SEN and inclusion, teaching practice could, for example, incorporate planned pupil-focused SEN and disability tasks, writing of portfolios and essays about SEN/disabilities. Such task designs have been found to improve trainees' learning about pupils with SEN and teaching approaches of relevance for them. They have also been found to promote attitudinal change and critical reflective practices among trainees. 
Also, the current study found that the mentors demonstrated inadequate inclusive pedagogical approaches. This stresses the need for professional development opportunities for school-based mentors to equip them with inclusive attitudes, knowledge and skills so as to enable them to effectively support trainees. Two trainees practicing teaching in the same classroom is a golden co-teaching opportunity. However, only few trainees took advantage of this opportunity. The current data highlight the need for more attention to be paid to the development of collaborative skills among trainees. The importance of collaboration with other teachers through coteaching must be taught and modelled to trainees. Further research could be carried out to specifically determine the extent to which mentoring and supervision of teaching practice can equip trainees with inclusive practices.

\section{References}

Agbenyega, J., \& Deku, P. (2011). Building new identities in teacher preparation for inclusive education in Ghana. Current Issues in Education, 14(1), 1-32.

Akyeampong, K., Lussier, K., Pryor, J., \& Westbrook, J. (2012). Improving Teaching and Learning of Basic Maths and Reading in Africa: Does Teacher Preparation Count? International Journal of Educational Development, 33(3), 272-282.

Alhassan, A. M. (2014). Implementation of Inclusive Education in Ghanaian Primary Schools: A Look at Teachers` Attitudes. American Journal of Educational Research, 2(3), 142-148. doi: 10.12691/education-2-3-5.

Alhassan, A. K., \& Abosi, O. C. (2014). Teacher Effectiveness in Adapting Instruction to the Needs of Pupils with Learning Difficulties in Regular Primary Schools in Ghana. Sage Open, 1 - 16, DOI: 10.1177/2158244013518929

Angelides, P., Stylianou, T., \& Gibbs, P. (2006). Preparing teachers for inclusive education in Cyprus. Teaching and Teacher Education, 22, 513-522.

Ainscow, M., Booth, T., \& Dyson, A. (2006). Improving Schools, Developing Inclusion. London: Routledge.

Arbeiter, S., \& Hartley, S. (2002). Teachers' and pupils' experiences of integrated education in Uganda, International Journal of Disability, Development and Education, 49(1), 61-78.

Avramidis, E., Bayliss, P., \& Burden, R. (2000). A survey into mainstream teachers' attitudes towards the inclusion of children with special needs in the ordinary school in one local education authority. Educational Psychology, 20(2), 193-213.

Casely-Hayford, L., Campbell, S., Seidu, A., \& Adams, R. (2013). The Quality and Inclusivity of Basic Education across Ghana's three northern regions: a look at learning effectiveness and efficiency in post 2015. UKFIET International Conference on Education and Development - Education \& Development Post 2015: Reflecting, Reviewing, Re-visioning. Oxford, 10-12 September 2013.

Chhabra, S., Srivastava, R., \& Srivastava, I. (2010). Inclusive education in Botswana: The perceptions of school teachers. Journal of Disability Policy Studies, 20(4), 219-228. DOI: $10.1177 / 1044207309344690$. 
Clarke, M., Lodge, A., \& Shevlin, M. (2012). Evaluating initial teacher education programmes: Perspectives from Republic of Ireland. Teaching and Teacher Education, 28, 141-153.

Croft, A. (2010). Including Disabled Children in Learning: Challenges in Developing Countries. Research monograph no. 36. Falmer: Create, University of Sussex.

Dako-Gyeke, M., \& Asumang, E. S. (2013). Stigmatisation and discrimination experiences of persons with mental illness: Insights from a qualitative study in Southern Ghana. Social Work and Society International Online Journal, 11(1); 1-14.

Dart, G. (2006). 'My eyes went wide open' - an evaluation of the special needs education awareness course at Molepolole College of Education, Botswana, British Journal of Special Education, 33(3), 130-138.

EADSNE. (2012). Teacher Education for Inclusion: Project Recommendation linked to Sources of Evidence, Odense, Denmark: European Agency for Development in Special Needs Education.

Florian, L., \& Black-Hawkins, K. (2011). Exploring Inclusive Pedagogy. British Educational Research Journal, 37(5), 813-828. doi: 10.1080/01411926.2010.501096

Florian, L., \& Rouse, M. (2009). The inclusive practice project in Scotland: Teacher education for inclusive education. Teaching and Teacher Education 25, 594-601.

Forlin, C. (2010). Future direction for teacher education for inclusion. In C. Forlin (Ed.), Teacher Education for Inclusion: Changing Paradigms and Innovative Approaches (pp. 246-252). Abingdon: Routledge.

Jelas, Z. M., (2010). Learner diversity and inclusive education: A new Paradigm for teacher education in Malaysia. Procedia and Behavioural Sciences, 7 (C), 201-204.

Jordan, A., Schwartz, E., \& McGhie-Richmond, D. (2009). Preparing teachers for inclusive classrooms. Teaching and Teacher Education, 25(4), 535-542.

Kuyini, A. B., \& Desai, I. (2009). Providing instruction to students with special needs in inclusive classrooms in Ghana: Issues and challenges. International Journal of Whole Schooling, 4(1), 22-39.

Le Fanu, G. (2013). The inclusion of inclusive education in international development: Lessons from Papua New Guinea. International Journal of Educational Development, 33(2), 139-148.

Lambe, J. (2007). Northern Ireland student teachers' changing attitudes towards inclusive education during initial teacher training. International Journal of Special Education, 22(1), 59-71.

Lambe, J., \& Bones, R. (2006). Student teachers' perceptions about inclusive classroom teaching in Northern Ireland prior to teaching practice experience. European Journal of Special Needs Education, 21(2), 167-186.

Lawson, H., Norwich, B., \& Nash, T. (2013). What trainees in England learn about teaching pupils with special educational needs/disabilities in their school-based work: the contribution of planned activities in one-year initial training courses? European Journal of Special Needs Education, 28(2), 136-155, DOI: 10.1080/08856257.2013.778115.

Mangope, B., \& Mukhopadhyay, S. (2015). Preparing teachers for inclusive education in Botswana: The role of professional development. Journal of International Special Needs Education, 18(2), 60-72.

McIntyre, D. (2009). The difficulties of inclusive pedagogy for initial teacher education and some thought on the way forward. Teaching and Teacher Education, (25), 602-608. 
Ministry of Education. (2015). Inclusive Education Policy. Ministry of Education, Republic of Ghana.

Nash, T., \& Norwich, B. (2010). The initial training of teachers to teach children with special educational needs: A national survey of English Post Graduate Certificate of Education programmes. Teaching and Teacher Education 26, 1471-1480.

Nketsia, W., Saloviita, T., \& Gyimah, E. K. (2016). Teacher Educators' Views on Inclusive Education and Teacher Preparation in Ghana. International Journal of Whole Schooling, 12(2), 1-18.

Nketsia, W., \& Saloviita, T. (2013). Pre-service teachers' views on inclusive education in Ghana, Journal of Education for Teaching, 39(4), 429-441, DOI:10.1080/02607476.2 013.797291 .

Oppenheim, A. N. (1992). Questionnaire, design, interviewing and attitude measurement. London: Pinter Pub Ltd.

Pallant, J., (2016). SPSS survival manual. 6th edition ed., London: Allen and Unwin.

Sawhney, S. (2015). Unpacking the nature and practices of inclusive education: the case of two schools in Hyderabad, India. International Journal of Inclusive Education, 19(9), 887-907, DOI: 10.1080/13603116.2015.1015178.

Sharma, U., Forlin, C., \& Loreman, T. (2008). Impact of training on pre-service teachers' attitudes and concerns about inclusive education and sentiments about persons with disabilities. Disability and Society, 23(7), 773-785.

Singal, N., Salifu, E. M., Iddrisu, K., Casely-Hayford, L., \& Lundebye, H. (2015). The impact of education in shaping lives: reflections of young people with disabilities in Ghana. International Journal of Inclusive Education, 19(9), 908-925, DOI: 10.1080/13603116.2015.1018343.

Scruggs, T., \& Mastropieri, M. (1996). Teacher perceptions of mainstreaming/inclusion, 1958-1995: A research synthesis. Exceptional Children, 63 (1), 59-74.

Strawderman, C., \& Lindsey, P. (1995). Keeping up with the times: Reform in teacher education. Journal of Teacher Education, 46, 95-100.

Swart, E., Engelbrecht, P., Eloff, I., \& Pettipher, R. (2004). Implementing inclusive education in South Africa: teachers' attitudes and experiences. Acta Academia, 34(1), 175-189.

Tabulawa, R. (2013). Teaching and Learning in Context: Why Pedagogical Reform Fail in Sub-Saharan Africa. Council for the Development of Social Science Research in Africa (CODESRIA), Dakar, Senegal.

Tungaraza, F. D. (2013). College Tutors' Attitudes towards Inclusive Education in Tanzania. Annals of Modern Education, 5(1), 24-39.

UNESCO. (2009). Policy Guidelines on Inclusion in Education. Paris: UNESCO.

UNESCO. (2000). World Education Forum. The Dakar Framework for Action: Education for All - Meeting our Collective Commitments. Paris, UNESCO.

UNESCO. (1994). The Salamanca Statement and Framework for Action on Special Needs Education. Presented at the World Conference on Special Needs Education: Access and Quality. Salamanca, Spain.

United Nations. (2006). Convention on the Rights of Persons with Disabilities and Optional Protocol. United Nations, New York. http://www.un.org/disabilities/default.asp?id = 150 Access date 30.08.2015. 
Villa, R. A., Thousand, J. A., Meyers, H., \& Nevin, A. (1996). Teacher and administrator perceptions of heterogenous education. Exceptional Children, 63(1), 29-45.

Wolfberg, P., LePage, P., Cook, E. (2009). Innovations in Inclusive Education: Two Teacher Preparation Programs at the San Francisco State University. International Journal of Whole Schooling, 5(2), 16-27.

Welch, M. (1996). Teacher education and the neglected diversity: Preparing educators to teach students with disabilities. Journal of Teacher Education, 47, 355-366.

West, E., Jones, P., \& Stevens, D. (2006). Teachers of students with low incidence disabilities talk about their own learning: An international insight, Research and Practice for Persons with Severe Disabilities, 39(3), 121-42.

West, E. A., (2010). Initial teacher training to meet the needs of students with disabilities who are culturally and linguistically diverse. In C. Forlin (Ed.), Teacher Education for Inclusion: Changing Paradigms and Innovative Approaches (pp. 208-214). Abingdon: Routledge.

Western Sydney University. (2018). Handbook - 102153 Professional Experience (Additional Needs). Western Sydney University. 